\title{
SCREENING FOR GLAUCOMA IN RURAL POPULATION: A HOSPITAL BASED STUDY
}

\author{
Rhutuja A. Deo', Bodhraj Dhawan², Smita Singh ${ }^{3}$ \\ ${ }^{1}$ Assistant Professor, Department of Ophthalmology, NKPSIMS, Nagpur. \\ ${ }^{2}$ Assistant Professor, Department of Ophthalmology, NKPSIMS, Nagpur. \\ 3Professor, Department of Ophthalmology, MGIMS, Sevagram.
}

\section{ABSTRACT}

AIM

To estimate the prevalence of blindness due to glaucoma in patients aged 40 years and above attending Tertiary Care Hospital.

\section{MATERIAL AND METHODS}

The study was conducted in the Department of Ophthalmology, Mahatma Gandhi Institute of Medical Sciences, Sevagram. Visual acuity, anterior segment examination and anterior chamber depth assessment by slit lamp, digital tension, non-contact tonometry, confrontation field test, fundus examination, direct ophthalmoscopy and fundus imaging was done. Gonioscopy and automated perimetry was done in glaucoma suspects.

\section{RESULTS}

7600 eyes of 3800 patients were examined, 108 eyes were diagnosed to have glaucoma. Based on the best corrected visual acuity, $15(13.8 \%)$ eyes and $8(0.22 \%)$ persons had visual impairment and $33(30.5 \%)$ eyes and $20(31.7 \%)$ persons were blind. The prevalence of glaucoma in eyes was $1.42 \%$. The prevalence of blindness due to glaucoma in eyes was $0.43 \%$ and person was $0.52 \%$. The prevalence of Primary Open Angle Glaucoma in eyes was 1\%, Primary Angle Closure Glaucoma in eyes was 0.15\%, Neovascular glaucoma in eyes was $0.07 \%$, Lens Induced Glaucoma in eyes was $0.17 \%$ and Pseudoexfoliative Glaucoma in eyes was $0.03 \%$. IOP $>20 \mathrm{mmHg}$ was present in 50(36.1\%) glaucomatous eyes, majority of the eyes being in Open Angle Glaucoma 24(31.5\%) eyes; $58(53.7 \%$ ) glaucomatous eyes had IOP in the range $11-20 \mathrm{mmHg}$, among them 38 eyes were on treatment and 20 eyes were operated.

\section{CONCLUSION}

Being an irreversible disease if diagnosed early, blindness can be avoided. So screening is very important for early diagnosis and their proper management thereon.

\section{KEYWORDS}

Glaucoma, Prevalence, Blindness.

HOW TO CITE THIS ARTICLE: Rhutuja A. Deo, Bodhraj Dhawan, Smita Singh. "Screening for Glaucoma in Rural Population: A Hospital Based Study." Journal of Evolution of Medical and Dental Sciences 2015; Vol. 4, Issue 99, December 10; Page: 16451-16456, DOI: $10.14260 /$ jemds/2015/2441

\section{INTRODUCTION}

Glaucoma being described as the "silent blinding disease" or the "sneak thief of sight." It progresses without warning nor obvious symptoms to the patient leading to worsening visual damage and irreversible blindness. ${ }^{1}$ (World Health Organization Data).

Worldwide glaucoma is the second most common cause of blindness. It is estimated that 4.5 million persons are globally blind due to glaucoma and by 2020 this number will rise to 11.2 million. $^{2}$ (Quigley et al. 2006) Twelve million Indians are affected by glaucoma accounting for $12.8 \%$ of the blindness in the country. ${ }^{3}$ (Thomas et al. 2003).

Due to silent nature of the disease, $50 \%$ of the affected persons in its early stages in the developed countries are not even aware of suffering from glaucoma. ${ }^{4}$ (Sommer et al. 1991) In underdeveloped countries, it may rise to $90 \%$. The lack of a uniform definition of the disease in its different forms makes it difficult to assess its public health impact. ${ }^{5}$ (Thylefors B et al. 1994).

Financial or Other, Competing Interest: None.

Submission 14-11-2015, Peer Review 16-11-2015,

Acceptance 02-12-2015, Published 10-12-2015.

Corresponding Author:

Dr. Rhutuja A. Deo,

Plot No.147, Vitthal Balaji Apt.

Telecom Colony,

Pratap Nagar-440022, Nagpur.

E-mail:drrhutujam@rediffmail.com

DOI:10.14260/jemds/2015/2441
Yet there is no permanent cure for glaucoma and blindness is irreversible. Medical or surgical treatment can only slow down the further progression of the vision loss. Therefore, early detection helps in preventing blindness. Hence, the present study "screening for glaucoma is aimed at adding insight into the cause of blindness, chiefly glaucoma in rural populations."

\section{OBJECTIVE}

To estimate the prevalence of blindness due to glaucoma in rural Tertiary Care Hospital.

\section{MATERIALS AND METHODS STUDY DESIGN}

It was an Observational/Cross-sectional/Prospective Hospital based study, in which all consecutive patients aged $40 \mathrm{yrs}$. and above attending the Eye Outpatient Department who gave informed consent were included in the study. Consecutive 3800 patients were selected from the routine Outpatient Department.

The study period was from September 2007 to August 2008.

\section{DEMOGRAPHIC DATA}

All the new patients above the age of 40 years attending the Outpatient Department were interviewed and demographic data of each patient was recorded in the form of address, habitat (whether rural and urban), literacy status, socioeconomic status and occupation. 


\section{HISTORY}

Each patient's detailed history regarding symptomatology was noted. Symptoms like headache, frequent change of glasses, missing side objects, bumping into objects, pain in eyes, gradual loss of central vision, rapid onset visual loss, distortion of straight lines or edges, blind spot in central or paracentral visual field, metamorphopsia, flashes of light, floaters, a curtain or shadow moving over the field of vision, peripheral or central visual loss were asked.

Enquiry about the family history of glaucoma, diabetes, history of cigarette smoking, h/o trauma was made. Any relevant history of systemic illnesses like diabetes, hypertension, tuberculosis, leprosy, bronchial asthma, thyroid diseases, AIDS, STD, collagen disorders, pregnancy, hereditary disorders, tumours was recorded. If the patient was a known case of glaucoma then type, duration, treatment and compliance was noted.

\section{OCULAR EXAMINATION}

\section{Visual acuity and best corrected visual acuity}

Visual acuity was evaluated with the Snellen's visual acuity chart, unaided, vision with glasses and with pin hole to determine the visual acuity. Retinoscopy was performed using Streak retinoscope (Heinz)/autorefractometry was done and Best Corrected Visual Acuity (BCVA) was recorded. Vision was then categorized according to the WHO Classification of Blindness. If the visual acuity could not be measured, visual acuity was assessed by counting fingers, hand movements and light perception.

\section{Anterior Segment Examination}

Following this was the anterior segment examination was done using torch light and slit lamp examination for ruling out any evidence of recent trauma, intraocular inflammation, intraocular surgery, corneal opacities, degeneration and dystrophy of cornea. Hirschberg test to rule out squint, position of eyeball to assess proptosis, exophthalmos, microphthalmia, phthisis, etc. was done. Eyelids were tested for entropion or ectropion trichiasis, etc.

Lacrimal sac infections were looked for by performing the regurgitation test. Any affectations of the conjunctiva were detected to rule out inflammation or infection. Any presence of a conjunctival filtering bleb was noted. Sclera was examined for its color, staphyloma, nodules. Then cornea was examined for surface irregularities, opacities, keratoconus, injury, degeneration, dystrophy, KPs etc. Anterior chamber depth was assessed using torchlight and slit lamp examination by Von Herick method.

Iris condition was evaluated and abnormalities like peripheral buttonhole iridectomy, iritis, rubeosis, atrophic patches, heterochromia, synechiae, nodules were looked for. Pupil was evaluated for its size, shape and reaction. Presence of pseudo-exfoliation was seen. Condition of the lens to rule out cataract, aphakia, pseudophakia, etc. was noted. Then presence of pseudoexfoliation was documented.

\section{Measurement of Intraocular Pressure}

Non-contact tonometry was performed using the TOPCON 300

Non-Contact Tonometer.

The intraocular pressure was measured in $\mathrm{mmHg}$.

\section{Fundus Imaging}

Digital imaging of posterior segment was done with ZEISS

Fundus Camera with at least $8 \mathrm{~mm}$ dilated pupils for recording of abnormal fundus findings.

\section{POSTERIOR SEGMENT EXAMINATION}

The routine fundus examination was done, which consisted of, 1. Preliminary examination at $1 \mathrm{~m}$.
2. Distant Direct Ophthalmoscopy: It was done at a distance of $22 \mathrm{~cm}$ from the patient and the results were interpreted.

3. Direct Ophthalmoscopy: In this method, the patient's eye was approached as closely as possible and fundus was observed and the results were interpreted by direct ophthalmoscope.

4. Indirect ophthalmoscopy using 20-D condensing lens with patient in supine position.

5. Slit lamp biomicroscopy: The slit lamp was also used to view the posterior part of vitreous and central fundus with pupillary dilation $>6 \mathrm{~mm}$ by interposing a 90 -D lens, optic nerve and macula was examined and all findings were recorded.

\section{GONIOSCOPY}

Gonioscopy was done in glaucoma suspects and proven glaucoma cases. (See operational definitions).

Using Goldman three mirror lens at $25 \mathrm{x}$ magnification, Gonioscopy was performed with the patient looking straight. A systematic approach was followed nasal angle-superiortemporal than inferior angle and findings recorded using Shaffer's grading. All abnormalities of angle including peripheral anterior synechiae were recorded.

\section{SHAFFER'S GRADING}

1. Grade 4: Wide open-from Schwalbe's line to ciliary body.

2. Grade 3: Open angle-from Schwalbe's line to scleral spur.

3. Grade 2: Moderately narrow-from Schwalbe's line to trabecular meshwork.

4. Grade 1: Very narrow-Schwalbe's line only.

5. Grade 0: Closed-None of the angle structures visible.

6. Any abnormal structure was seen if any abnormality was present.

\section{AUTOMATED PERIMETRY}

The automated perimeter was performed on the Humphrey Automated Perimeter. The test 30-2 SITA STANDARD with fovea on program was used. It was done in glaucoma cases.

The patient was seated with his head at the centre of an illuminated hemisphere. An appropriate corrective lens was placed in front of the to be examined and the other eye was occluded. The patient was instructed to maintain a constant fixation at a specific target and press a button when perceived a light stimulus within the visual field. A computer presented a stimuli of varying luminance at different locations. The threshold values of an individual were then compared by computer to age matched normal values and interpreted.

\section{OPERATIONAL DEFINITIONS \\ BLINDNESS}

1. WHO classification of visual impairment and blindness (Adapted from International Statistical classification of diseases and related health problems, tenth revision. Geneva, World Health Organization, 1992). ${ }^{6}$

\begin{tabular}{|c|c|}
\hline $\begin{array}{c}\text { Category of } \\
\text { Visual Impairment }\end{array}$ & $\begin{array}{c}\text { Best Corrected Visual Acuity } \\
\text { (BCVA) in the Better Eye } \\
\text { (WHO) }\end{array}$ \\
\hline 0 Normal & $6 / 6$ to $6 / 18$ \\
\hline 1. Visual Impairment & $<6 / 18$ to $6 / 60$ \\
\hline $\begin{array}{c}\text { 2. Severe Visual } \\
\text { Impairment }\end{array}$ & $<6 / 60$ to $3 / 60$ \\
\hline 3. Blind & $<3 / 60$ to $1 / 60$ \\
\hline 4. Blind & No light perception \\
\hline 5. Blind & \\
\hline $\begin{array}{c}\text { 9. Undetermined or } \\
\text { unspecified }\end{array}$ & \\
\hline
\end{tabular}




\section{GLAUCOMA}

Primary Open Angle Glaucoma (POAG) was diagnosed in the presence of characteristics optic disc cupping (cup/disc ratio 0.5 ) and/or visual field changes and open on gonioscopy. The presence of high IOP was not considered essential, since upto one third may be 'low tension glaucoma' which were therefore included as POAG in the. ${ }^{5}$ (Thylefors B et al. 1994).

Primary Angle Closure (PACG) when there was evidence of an occludable angle history of symptoms, disc cupping (cup/disc ratio 0.5); visual field defects (s) history of specified surgery and a possible provocative test. ${ }^{5}$ (Thylefors B et al. 1994).

Secondary glaucoma when evidence of triad of signs was associated with known ocular or systemic disease; since such case are often unilateral and blindness is usually caused by the primary disorders, the number of blinds resulting from

\begin{tabular}{|c|c|c|}
\hline Visual Status & $\begin{array}{c}\text { Presenting } \\
\text { Visual Acuity } \\
\text { n(\%) }\end{array}$ & $\begin{array}{c}\text { Best Corrected } \\
\text { Visual Acuity } \\
\text { n(\%) }\end{array}$ \\
\hline $\begin{array}{c}\text { Near normal } \\
6 / 6-6 / 18\end{array}$ & $26(41.27)$ & 34 (53.97) \\
\hline $\begin{array}{c}\text { Visually impaired } \\
<6 / 18-6 / 60\end{array}$ & $14(22.22)$ & 8 (12.69)) \\
\hline $\begin{array}{c}\text { Severe visual } \\
\text { impairment } \\
<6 / 60-3 / 60\end{array}$ & 1 (1.59) & 1 (1.59) \\
\hline$<3 / 60-1 / 60$ & $7(11.11)$ & $5(7.94))$ \\
\hline$<1 / 60-\mathrm{PL}+$ & $14(22.22)$ & $14(22.22))$ \\
\hline PL Negative & $1(1.59)$ & $1(1.59))$ \\
\hline Total & $63(100)$ & $63(100)$ \\
\hline \multicolumn{3}{|c|}{$\begin{array}{c}\text { Table 1: Prevalence of Blindness and Visual } \\
\text { Impairment due to Glaucoma in Hospital Patients } \\
\text { (n=3800 Individuals) }\end{array}$} \\
\hline
\end{tabular}

Visual Status in Glaucoma (Eyes) (Table -2)

Out of the 7600 eyes examined, 108 (1.42\%) eyes were diagnosed as suffering from glaucoma. Presenting Visual Acuity was near normal in $48(44.44 \%)$ eyes; $25(11.5)$ eyes had visual impairment and 35(59.1\%) eyes were blind.

Based on the Best Corrected Visual Acuity, 60(55.6\%) eyes had near normal visual acuity, $15(13.08 \%)$ eyes had visual impairment and 33(30.6\%) eyes were blind. secondary glaucoma was not determined. ${ }^{5}$ (Thylefors B et al. 1994).

\section{RESULTS}

Prevalence of blindness and visual impairment due to glaucoma in hospital patients (Table -1)

Out of the 3800 included in study, 63(1.65\%) individuals were diagnosed as suffering from glaucoma. Presenting Visual Acuity in 26(0.68\%) individuals were near normal, 15(0.38\%) individuals had visual impairment and 22 individuals $(0.57 \%)$ were blind.

Based on recording the BCVA, 34 individuals $(0.89 \%)$ had near normal visual acuity, 9 individuals $(0.23 \%)$ had visual impairment, and $20(0.52 \%)$ were blind including 1(0.02) with PL negative.

Severe Visual Impairment $(<6 / 60-3 / 60)$ was not found in glaucomatous eyes.

\begin{tabular}{|c|c|c|}
\hline Visual Status & $\begin{array}{c}\text { Presenting } \\
\text { Visual Acuity } \\
\text { n (\%) }\end{array}$ & $\begin{array}{c}\text { Best Corrected } \\
\text { Visual Acuity } \\
\text { n (\%) }\end{array}$ \\
\hline $\begin{array}{c}\text { Near normal } \\
6 / 6-6 / 18\end{array}$ & $48(44.45)$ & $60(55.55)$ \\
\hline $\begin{array}{l}\text { Visual impairment } \\
<6 / 18-6 / 60\end{array}$ & 25 (23.15) & 15 (13.89) \\
\hline $\begin{array}{c}\text { Blind } \\
<3 / 60-1 / 60 \\
\end{array}$ & $1(0.94)$ & $1(0.94)$ \\
\hline$<1 / 60-\mathrm{PL}+$ & $10(9.26)$ & $08(7.40)$ \\
\hline PL Negative & $24(22.23)$ & $24(22.22)$ \\
\hline Total & $108(100)$ & $108(100)$ \\
\hline
\end{tabular}

Age group distribution of blindness and visual impairment in hospital (Persons) (Table -3)

We examined 3800 persons, 63 persons were diagnosed to have glaucoma, based on best corrected visual acuity, $8(12.7 \%)$ persons had visual impairment, $1(1.6 \%)$ persons had severe visual impairment and blindness was present in $20(28.1 \%)$ persons, majority in the age group $60-79$ years.

\begin{tabular}{|c|c|c|c|c|c|}
\hline \multirow[b]{2}{*}{$\begin{array}{l}\text { Best Corrected } \\
\text { Visual Acuity (WHO) }\end{array}$} & \multicolumn{5}{|c|}{ AGE GROUP IN YEARS } \\
\hline & $\begin{array}{l}40-49 \\
n(\%)\end{array}$ & $\begin{array}{l}\text { 50-59 } \\
\text { n(\%) }\end{array}$ & $\begin{array}{l}\text { 60-69 } \\
n(\%)\end{array}$ & $\begin{array}{l}\text { 70-79 } \\
\text { n(\%) }\end{array}$ & $\begin{array}{l}\text { Total } \\
\text { n(\%) }\end{array}$ \\
\hline $\begin{array}{c}\text { Near Normal } \\
6 / 6-6 / 18 \\
\end{array}$ & $\begin{array}{c}11(34.3) \\
(78.7)\end{array}$ & $\begin{array}{c}12(34.2) \\
(85.7) \\
\end{array}$ & 9 (25.7) (39.1) & $2(5.7)(39.1)$ & $\begin{array}{c}34 \\
(53.9) \\
\end{array}$ \\
\hline $\begin{array}{c}\text { Visual Impairment } \\
<6 / 18-6 / 60\end{array}$ & 0 & 0 & $5(62.5)(21.7)$ & $5(62.5)(21.7)$ & 8 (12.7) \\
\hline $\begin{array}{c}\text { Blind } \\
<6 / 60-3 / 60\end{array}$ & 0 & 0 & $1(100)(4.3)$ & $1(100)(4.3)$ & $1(1.6)$ \\
\hline$<3 / 60-1 \backslash 60$ & $1(20)(7.1)$ & $1(20)(7.1)$ & $2(40)(8.7)$ & $2(40)(8.7)$ & $5(7.9)$ \\
\hline $1 \backslash 60-\mathrm{PL}+$ & 1 (7.1) (7.1) & $1(7.1)(7.1)$ & $6(42.9)(26.1)$ & $6(42.9)(26.1)$ & $\begin{array}{c}14 \\
(22.3) \\
\end{array}$ \\
\hline PL negative & $1(100)(7.1)$ & 0 & 0 & 0 & $1(1.6)$ \\
\hline Total & $14(22.2)$ & $14(22.2)$ & $23(36.6)$ & $12(19.0)$ & 63 \\
\hline \multicolumn{6}{|c|}{$\begin{array}{l}\text { Table 3: Age Group Distribution of Blindness and Visual } \\
\text { Impairment of Glaucoma (Persons) }\end{array}$} \\
\hline
\end{tabular}

Age group distribution of blindness and visual impairment in glaucomatous eyes (Table -4)

We examined 7600 eyes, 108 eyes had glaucoma. After best corrected visual acuity, 15(13.8\%) eyes were visually impaired. Out of 108 eyes with glaucoma, according to WHO, blindness was found in 33(30.6\%) eyes, among them $9(26.4 \%)$ eyes in age group 40-49 years, $17(50 \%)$ eyes were in $50-59$ years, $7(20.5 \%)$ eyes in $60-69$ years 


\begin{tabular}{|c|c|c|c|c|c|}
\hline \multirow{2}{*}{$\begin{array}{c}\text { Best Corrected } \\
\text { Visual Acuity(WHO) }\end{array}$} & \multicolumn{5}{|c|}{ AGE GROUP IN YEARS } \\
\hline & $\begin{array}{l}40-49 \\
\text { n }(\%)\end{array}$ & $\begin{array}{l}\text { 50-59 } \\
\text { n (\%) }\end{array}$ & $\begin{array}{l}\text { 60-69 } \\
\text { n (\%) }\end{array}$ & $\begin{array}{l}70-79 \\
\text { n (\%) }\end{array}$ & $\begin{array}{l}\text { Total } \\
\text { n (\%) }\end{array}$ \\
\hline $\begin{array}{c}\text { Near Normal } \\
6 / 6-6 / 18\end{array}$ & $\begin{array}{c}36(60) \\
(72)\end{array}$ & $\begin{array}{c}16(26.7) \\
(41)\end{array}$ & $\begin{array}{c}7(11.7) \\
(38.9)\end{array}$ & $\begin{array}{l}1(1.6) \\
(100)\end{array}$ & $60(55.6)$ \\
\hline $\begin{array}{l}\text { Visually Impaired } \\
<6 / 18-6 / 60\end{array}$ & $\begin{array}{c}5(33.3) \\
(10)\end{array}$ & $\begin{array}{l}6(40) \\
(15.4)\end{array}$ & $\begin{array}{c}4(26.7) \\
(22.2)\end{array}$ & 0 & $15(3.8)$ \\
\hline $\begin{array}{c}\text { Blind } \\
<3 / 60-1 / 60\end{array}$ & 0 & $\begin{array}{c}1(100) \\
(2.6)\end{array}$ & 0 & 0 & $1(0.9)$ \\
\hline$<1 / 60-\mathrm{PL}+$ & $\begin{array}{c}3(37.5) \\
(12)\end{array}$ & $\begin{array}{l}4(50) \\
(10.2)\end{array}$ & $\begin{array}{c}1(12.5) \\
(5.6)\end{array}$ & 0 & $8(7.5)$ \\
\hline PL Negative & $\begin{array}{c}6(25) \\
(12)\end{array}$ & $\begin{array}{c}12(50) \\
(13.8)\end{array}$ & $\begin{array}{l}6(25) \\
(33.3)\end{array}$ & 0 & $24(22.2)$ \\
\hline Total & $50(46.2)$ & $\begin{array}{c}39 \\
(36.1)\end{array}$ & $\begin{array}{c}18 \\
(16.7)\end{array}$ & $1(1)$ & $108(100)$ \\
\hline
\end{tabular}

Intraocular tension in general population in eyes of hospital patients (Table -5)

7588 eyes were evaluated in the hospital, majority of the 6579 (86.7\%) eyes had IOP in the range of $11-20 \mathrm{mmHg}$; 959 eyes (12.64\%) had IOP <10mmHg. In 50(0.66\%) eyes, IOP > 20mmHg was noted.

\begin{tabular}{|c|c|c|c|c|c|c|}
\hline \multirow{2}{*}{$\begin{array}{l}\text { Intraocular } \\
\text { Pressure } \\
\text { Group } \\
\text { (mm/Hg) }\end{array}$} & \multicolumn{5}{|c|}{ Age Group in Years } & \multirow[b]{2}{*}{$\begin{array}{l}\text { Total } \\
\text { n(\%) }\end{array}$} \\
\hline & $\begin{array}{l}40-49 \\
\text { n(\%) }\end{array}$ & $\begin{array}{c}50-59 \\
\text { n(\%) }\end{array}$ & $\begin{array}{l}\text { 60-69 } \\
\text { n(\%) }\end{array}$ & $\begin{array}{l}70-79 \\
\text { n(\%) }\end{array}$ & $\begin{array}{c}80-89 \\
\text { n \%) }\end{array}$ & \\
\hline$<10$ & $\begin{array}{c}280(29.1) \\
(10)\end{array}$ & $\begin{array}{c}213(22.1) \\
(11.8)\end{array}$ & $\begin{array}{c}294(30.6) \\
(14.5)\end{array}$ & $\begin{array}{c}152(15.8) \\
(17.9)\end{array}$ & $\begin{array}{c}20(2.1) \\
(21.2)\end{array}$ & $959(12.64)$ \\
\hline $11-15$ & $\begin{array}{c}2327(38.4) \\
(82.8) \\
\end{array}$ & $\begin{array}{c}1466(24.2) \\
(80.8) \\
\end{array}$ & $\begin{array}{c}1570(25.9) \\
(77.7)\end{array}$ & $\begin{array}{c}621(10.3) \\
(72.9)\end{array}$ & $\begin{array}{c}71(1.2) \\
(75.6) \\
\end{array}$ & 6055 (79.79) \\
\hline $16-20$ & $\begin{array}{c}197(37) \\
(7)\end{array}$ & $\begin{array}{c}123(23.1) \\
(6.8)\end{array}$ & $\begin{array}{c}134(25.5) \\
(6.6)\end{array}$ & $\begin{array}{c}67(12.6) \\
(7.9)\end{array}$ & $\begin{array}{c}3(0.6) \\
(3.2)\end{array}$ & $524(6.91)$ \\
\hline $21-25$ & $\begin{array}{c}3(15.8) \\
(0.2) \\
\end{array}$ & $\begin{array}{c}3(15.8) \\
(0.15)\end{array}$ & $\begin{array}{c}6(31.6) \\
(0.4)\end{array}$ & $\begin{array}{c}7(36.8) \\
(0.8) \\
\end{array}$ & 0 & $19(0.26)$ \\
\hline $26-30$ & $\begin{array}{c}1(16.7) \\
(0.03)\end{array}$ & $\begin{array}{l}3(50) \\
(0.15)\end{array}$ & $\begin{array}{c}1(16.7) \\
(0.1)\end{array}$ & $\begin{array}{c}1(16.7) \\
(0.1)\end{array}$ & 0 & $6(0.08)$ \\
\hline $31-35$ & $\begin{array}{c}1(14.3) \\
(0.03)\end{array}$ & $\begin{array}{c}1(14.3) \\
(0.05)\end{array}$ & $\begin{array}{c}4(57.1) \\
(0.2)\end{array}$ & $\begin{array}{c}1(14.3) \\
(0.1)\end{array}$ & 0 & $7(0.09)$ \\
\hline $36-40$ & 0 & $\begin{array}{c}3(37.5) \\
(0.15)\end{array}$ & $\begin{array}{c}5(62.5) \\
(0.3)\end{array}$ & 0 & 0 & $8(0.10)$ \\
\hline$>40$ & $\begin{array}{l}1(10) \\
(0.03) \\
\end{array}$ & $\begin{array}{c}2(20) \\
(0.1) \\
\end{array}$ & $\begin{array}{c}4(40) \\
(0.2) \\
\end{array}$ & $\begin{array}{c}3(30) \\
(0.3) \\
\end{array}$ & 0 & $10(0.13)$ \\
\hline Total & 2810 (37) & $1814(23.9)$ & $2018(26.7)$ & $852(11.2)$ & $94(1.2)$ & $7588(100)$ \\
\hline
\end{tabular}

Distribution of type glaucoma in hospital patients (Table -6)

Out of 3800 patients, glaucoma was diagnosed in 63(1.65\%) patients. Among 63 patients, the prevalence of Open Angle Glaucoma was $1 \%$, Lens induced glaucoma $0.34 \%$, Angle Closure Glaucoma $0.16 \%$, Neovascular Glaucoma 0.13\% and PEX $0.02 \%$.

Out of 7600 eyes, 108(1.42\%) eyes had glaucoma. Open Angle Glaucoma (OAG) was found in 76(1\%) eyes followed by Angle Closure Glaucoma 12(0.15\%), Neovascular glaucoma 5(0.07\%), 13(0.17\%) eyes had Lens induced glaucoma and PEX in 2(0.03\%) eyes.

\begin{tabular}{|c|c|c|}
\hline Types of Glaucoma & $\begin{array}{c}\text { No. of Individual } \\
\text { n (\%) }\end{array}$ & $\begin{array}{c}\text { No. of Eyes } \\
\text { n (\%) }\end{array}$ \\
\hline Primary Open Angle Glaucoma & $38(60.31)$ & $76(70.38)$ \\
\hline Primary Angle Closure Glaucoma & \multirow{2}{*}{$6(9.53)$} & \multirow{2}{*}{$12(11.11)$} \\
\hline \multirow{4}{*}{$\begin{array}{cc}\text { Secondary glaucoma } \\
\text { - } \quad \text { Lens Induced Glaucoma } \\
\text { - } \quad \text { Neovascular Glaucoma } \\
\text { - } \quad \text { Pseudoexfoliative Glaucoma }\end{array}$} & & \\
\hline & $13(20.63)$ & $13(12.03)$ \\
\hline & $5(7.94)$ & $5(4.63)$ \\
\hline & $1(1.59)$ & $2(1.85)$ \\
\hline Total & $63(100)$ & $108(100)$ \\
\hline
\end{tabular}

Intraocular pressure distribution in types of glaucoma in eyes of hospital patients (Table -7)

Out of 7600 eyes examined in the hospital, 108 eyes were diagnosed as glaucoma, IOP $>20 \mathrm{mmHg}$ was present in $50(36.1 \%)$ glaucomatous eyes, majority of the eyes being in Open Angle Glaucoma 24(31.5\%) eyes; 58(53.7\%) glaucomatous eyes had IOP in the range $11-20 \mathrm{mmHg}$ among them 38 eyes were on treatment and 20 eyes were operated. 


\begin{tabular}{|c|c|c|c|}
\hline Types of Glaucoma & $\begin{array}{l}11-20 \\
\text { n (\%) }\end{array}$ & $\begin{array}{c}>20 \\
\text { n ( \%) }\end{array}$ & $\begin{array}{l}\text { Total } \\
\text { n (\%) }\end{array}$ \\
\hline Open Angle Glaucoma & $\begin{array}{c}52(68.8) \\
(89.6)\end{array}$ & $\begin{array}{c}24(31.5) \\
(48)\end{array}$ & $76(70.4)$ \\
\hline Lens Induced Glaucoma & 0 & $\begin{array}{c}13(100) \\
(26)\end{array}$ & $13(12.0)$ \\
\hline Angle Closure Glaucoma & $\begin{array}{c}4(33.3) \\
(6.8)\end{array}$ & $\begin{array}{c}8(66.6) \\
(16)\end{array}$ & $12(11.1)$ \\
\hline Neovascular Glaucoma & $\begin{array}{c}1(20) \\
(1.8)\end{array}$ & $\begin{array}{c}4(80) \\
(8)\end{array}$ & $5(4.6)$ \\
\hline $\begin{array}{l}\text { Pseudoexfoliative } \\
\text { Glaucoma }\end{array}$ & $\begin{array}{c}1(50) \\
(1.8)\end{array}$ & $\begin{array}{c}1(50) \\
(2)\end{array}$ & $2(1.9)$ \\
\hline Total & $58(53.7)$ & $50(36.1)$ & $108(100)$ \\
\hline
\end{tabular}

\section{DISCUSSION}

This hospital based study 'Screening for Glaucoma in Rural Population' assessed the prevalence of blindness due to Glaucoma. Improvement in the diagnosis of early cases of glaucoma will help to know the exact prevalence.

Study included 1970(51.8\%), males and 1830(48.2\%) females. Mean age of the patients was $54.95 \pm 10.83$ years. (Range 40-87 years). Mean age for males was $56 \pm 11.1$ years and mean age for females was $53 \pm 10.3$ years.

We measured intraocular pressure by applanation tonometer three times and mean were recorded. Visual field by perimetry, fundus examination by ophthalmoscope and gonioscopy was done.

Glaucoma was detected in 108 eyes (1.42\%) of 63 persons (1.65\%). Open Angle Glaucoma (POAG) was detected in $1 \%$ of persons and Primary Angle Closure Glaucoma (PACG) was in $0.15 \%$. Based on the best corrected visual acuity $15(13.8 \%)$ eyes and $8(0.22 \%)$ persons had visual impairment and $33(30.5 \%)$ eyes and $20(31.7 \%)$ persons were blind. The prevalence of glaucoma in eyes was $1.42 \%$. The prevalence of blindness due to glaucoma in eyes was $0.43 \%$ and person was $0.52 \%$.

We also diagnosed secondary glaucoma in eyes of persons as Neovascular glaucoma $(0.07 \%)$, Lens Induced Glaucoma (0.17\%) and Pseudoexfoliative Glaucoma (0.03\%).

This study had estimated the lower prevalence rate as compared to other studies. Being a hospital based study, we had included patients of 40 years and above who came to Ophthalmology Department with eye complaints, which did not represent the total population with eye disease. Optical coherent tomography, blood flow measurement at optic disc, scanning laser ophthalmoscopy and Heidelberg retinal tomography, which required for early diagnosis of glaucoma were not performed, hence these cases were missed.

There can also be a physiological variation in intraocular pressure, cup disc ratio, variation in sample size and criteria for diagnosis of glaucoma. Hence, our study had estimated the low prevalence as compared to other studies which are stated below.

\begin{tabular}{|c|c|c|c|c|}
\hline AUTHOR & SETTING & AGE GROUP & $\begin{array}{c}\text { PERSONS } \\
\text { EXAMINED }\end{array}$ & $\begin{array}{c}\text { PREVALENCE } \\
\text { OF GLAUCOMA }\end{array}$ \\
\hline $\begin{array}{c}\text { Ramakrishnan et al. } \\
(2003) . .^{7}\end{array}$ & $\begin{array}{c}\text { Southern districts of } \\
\text { Tamil Nadu }\end{array}$ & $\begin{array}{c}40 \text { years and } \\
\text { above }\end{array}$ & 5150 & $2.6 \%$ \\
\hline Foster et al. (2000). 8 & Chinese people & $40-79$ years & 1232 & $2.2 \%$ \\
\hline $\begin{array}{c}\text { Palimkar et al. } \\
(2008) .{ }^{9}\end{array}$ & $\begin{array}{c}\text { Rajanangaon district of } \\
\text { Chhattisgarh }\end{array}$ & $>35$ years & 7438 & $3.68 \%$ \\
\hline $\begin{array}{c}\text { Raychaudhuri et al. } \\
(2005) .10\end{array}$ & Rural West Bengal & $>50$ years & 1594 & $3.4 \%$ \\
\hline
\end{tabular}

Types of Glaucoma

\begin{tabular}{|c|c|c|c|c|}
\hline AUTHOR & SETTING & AGE GROUP & $\begin{array}{c}\text { PERSONS } \\
\text { EXAMINED }\end{array}$ & $\begin{array}{c}\text { PREVALENCE } \\
\text { OF TYPE GLAUCOMA }\end{array}$ \\
\hline $\begin{array}{c}\text { Ramakrishnan } \\
\text { et al. (2003). }{ }^{7}\end{array}$ & $\begin{array}{c}\text { Southern districts of } \\
\text { Tamil Nadu }\end{array}$ & $\begin{array}{c}40 \text { years and } \\
\text { above }\end{array}$ & 5150 & $\begin{array}{c}\text { POAG }-1.7 \% \\
\text { PACG }-0.5 \%\end{array}$ \\
\hline $\begin{array}{c}\text { Foster et al. } \\
(1996) .11\end{array}$ & $\begin{array}{c}\text { Hovsgol province, } \\
\text { northen Monglia }\end{array}$ & $>40$ years & 942 & $\begin{array}{c}\text { POAG }-0.5 \% \\
\text { PACG }-1.4 \%\end{array}$ \\
\hline $\begin{array}{c}\text { Bourne et al. } \\
(2003) .12\end{array}$ & Thai subjects & $>50$ years & 701 & $\begin{array}{c}\text { POAG }-2.3 \% \\
\text { PACG }-0.9 \%\end{array}$ \\
\hline
\end{tabular}




\section{CONCLUSION}

Being an irreversible disease, if diagnosed early, blindness can be avoided. So screening is very important for early diagnosis of the disease and their proper management thereon.

\section{REFERENCES}

1. World Health Organization data from www.who. int/blindness/causes/priority/en/.

2. Quigley HA, Broman AT. The number of people with glaucoma worldwide in 2010 and 2020. Br J Ophthalmol 2006;90:262-267.

3. Thomas R, Paul P, Maliyal J. Glaucoma in India. J glaucoma 2003;12:81-7.

4. Sommer A, Tielsch JM, Katz J, Quigley HA, Gottsch JD, Javitt J, Singh K. Relationship between intraocular pressure and primary open angle glaucoma among white and black Americans. The Baltimore Eye Survey Arch Ophthalmol 1991 Aug;109(8):1090-5.

5. Thylefors B \& Negrel A-D. The global impact of glaucoma* WHO Bulletin OMS Vol 72199.

6. Parsons' Diseases of the Eye, twentieth Edition: The causes and Prevention of Blindness. page no 523.

7. Ramakrishnan R. Glaucoma in a rural population of Southern India. The Aravind Comprehensive Eye Survey. Ophthalmology 2003;110:1484-1490.
8. Foster Paul J, Oen Francis TS, Machin David, Ng Tze-pin, Devereux Joe G, Johnson Gordon J, Khaw Reng T, Seah Steve KL. The Prevalence of Glaucoma in Chinese Residents of Singapore. A Cross-Sectional Population Survey of The Tanjong Pager District. Arch Ophthalmol 2000;118:1105-1111.

9. Palimkar Anand, Khanderkar Rajiv, Venkataraman V. Prevalence and distribution of glaucoma in Central India (Glaucoma survey- 2001). Indian Jr Ophthalmology 2008;56;57-62.

10. Raychaudhuri A, Lahiri SK, Bandyopadhyay M, Foster PJ. A population based survey of the prevalence and type of glaucoma in rural West Bengal: The West Bengal Glaucoma Study. British Jr Ophthalmol 2005;89:1559-1564.

11. Foster Paul J, Baasanhu Jamyanjav, Alsbirk Poul Helge, Munkhbayar Dorj, Uranchimeg Davaatseren, Johnson Gordon J. Glaucoma in Mongolia. A population-based survey in Hovsgol Province, Northern Mongolia. Arch ophthalmol 1996;114:1235-1241.

12. Bourne RRA, Sukudom P, Foster PJ, Tantisevi V, Jitapunkul S, Lee PS, Johnson GJ, Rojanapongpun P. Prevalence of glaucoma in Thailand: a population based survey in Rom Klao District, Bangkok. British Jr Ophthalmol 2003;87:1069-1074. 